The Book of Fermentology

\title{
Inuit Fermentation:
}

\section{Animal-Based \& Archaic [enriched transcript]}

Aviaja Lyberth Hauptmann 1

${ }^{1}$ University of Greenland

NC State University Libraries

Published on: Dec 03, 2021

License: Creative Commons Attribution 4.0 International License (CC-BY 4.0). 
Editor's note: This publication contains the video of the talk from the Fermentology webinar series, as well as a lightly edited transcript of the lecture. The transcript has been enriched with media, annotations, and links to other material by the digital publication team in order to amplify and extend the content for a reading experience.

\section{Abstract}

As part of the Arctic Indigenous diet, Inuit fermented foods are all animal-sourced, even the ones made from plants. From the stomach content of the caribou to the seabirds in sealskins, this short seminar introduces Inuit fermented foods illustrating how these rare foods present us with an opportunity to appreciate the diversity of dishes and flavors that might come from an entirely animal-sourced diet. Aviaja Hauptmann, who is an Inuk microbiologist, will discuss the role that Inuit fermentation has played and has the potential to play in the future.

Image attribution: Narwhal intestine drying by Daniel Hauptmann ( $\odot$ Aviaja Hauptmann)

\section{Watch the talk}

Visit the web version of this article to view interactive content.

Inuit Fermentation: Animal-based \& Archaic with Aviaja Hauptmann

\section{Introduction}

Today I'm going to give a brief overview of Inuit fermentation practice from my perspective. And before I go into the fermentation practice, I just want to make sure that everyone knows what I'm talking about when I say 'Inuit.'

As Inuit, we are an Indigenous population to the Arctic region. The Inuit live in all of the circumpolar region all the way from Russia over Alaska and Canada all the way to Kalaallit Nunaat, Greenland, which is part of the Kingdom of Denmark.

Visit the web version of this article to view interactive content.

$\underline{\text { Inuit Culture in Greenland by VisitGreenland }}$ 
The Inuit fermentations that I'm going to introduce today are all from Kalaallit Nunaat, Greenland, where I am from. And most of the ferments that I'll be presenting are from the west coast of Greenland.

\section{The Inuit Diet}

The most basic thing one needs to know about the Inuit diet, not just the fermented foods but the diet in general, is that it is animal sourced. August Krogh, who's a Danish Nobel Laureate, described the diet of the "Eskimo" as an extremely close analogy to those of the large carnivorous animals.

The diet on the east coast of Greenland in 1885 closely resembled the original Inuit $\operatorname{diet}[1]$. Back then the diet was comprised of $45 \%$ protein energy and $55 \%$ fat energy. That leaves $0 \%$ for carbohydrate energy, which means that there was essentially no plants in this diet. Maybe through a short period in the summertime there had been some plants, but not enough to actually make up a lot of the energy in this diet.

This is a very strong contrast to what we today believe as being a healthy diet. What you see here is the Danish diet pyramid. 


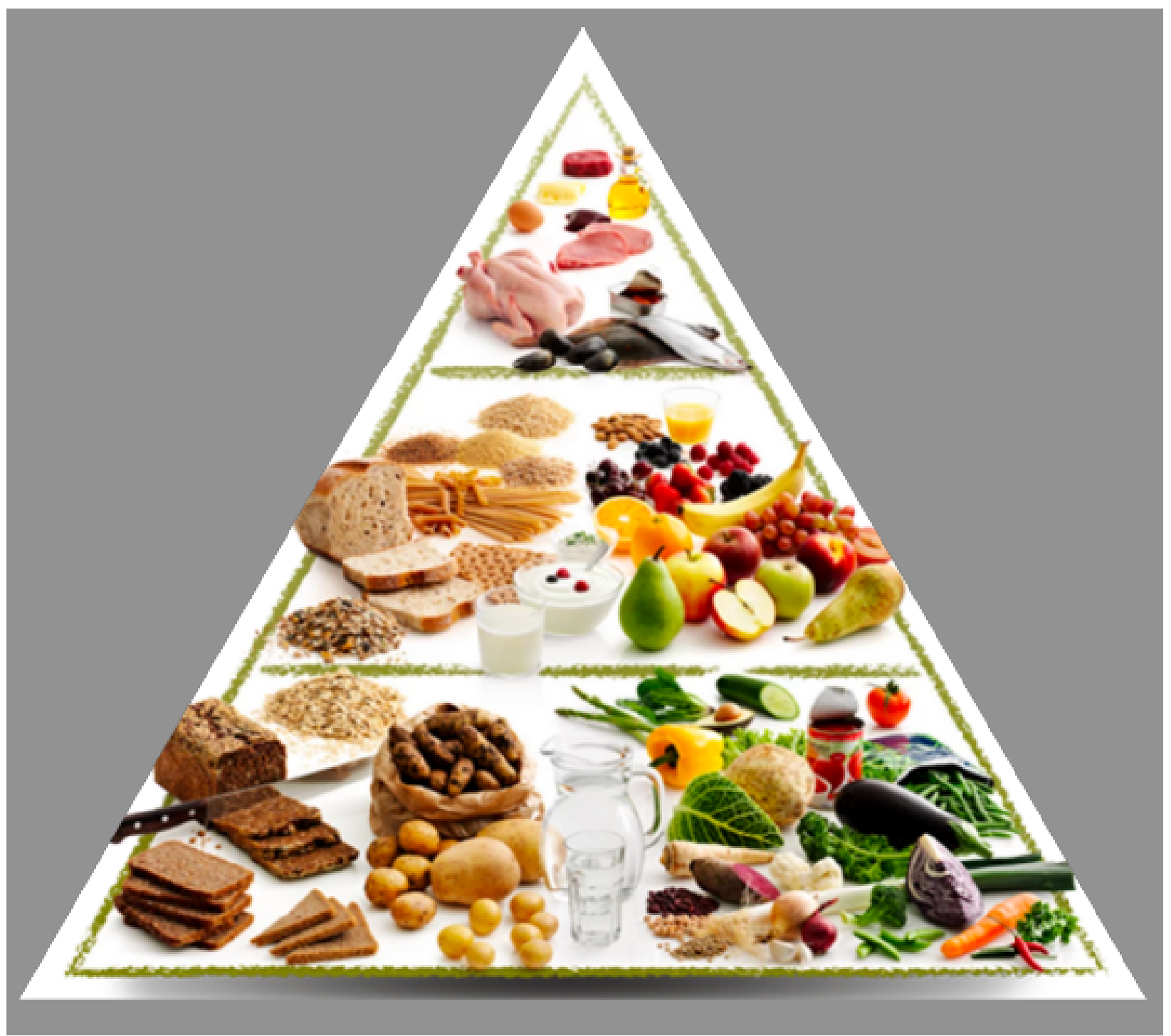

Madpyramiden/Food pyramid by Coop ( (

You could take the Inuit diet and then turn that diet pyramid upside down, because we've eaten basically just what's on top and almost nothing at the bottom of the diet pyramid.

One of the things that is conventionally believed about an animal sourced diet is that it's not very varied. There's this notion that you can eat the rainbow in colors in plants and you'll be healthy. I believe it's because if we go into our supermarkets and we look at the vegetable aisle, we see a lot of different colors. That gives us an impression of diversity. We also know that different fruits and vegetables can have sweet tastes, sour tastes, or bitter tastes; and they all have different shapes and textures. 
We instinctively know that plants can be diverse. But we don't think about animal sourced foods in the same way. An animal sourced food can be a very diverse diet. If you look at the fermented foods from an animal sourced diet, you can be convinced that it can be a very diverse diet.

Visit the web version of this article to view interactive content.

Aviaja Lyberth Hauptmann on how the world's diet revolution is challenging Greenland on The

Nordic FoodTech Podcast hosted by Analisa Winther

\section{Sea Mammals}

We've been trailing through a lot of historical literature about Inuit fermented foods from Greenland. Some of these foods are still made today, and some of them aren't.

The sea mammals, and in particular the seal, is sort of the cornerstone of the Inuit diet. Within the seal, there's a diversity of fermented foods. You can ferment entire carcasses with the bowels left in them. You can ferment the flesh or the entrails, the blood, the flippers, the blubber filled into bags made of seal stomachs.

This one called Iginneq is the blubber that has been filled into bags made of seal stomachs. It gets this brown color on the outside because you put it in the sun before you leave it to ferment, and then it's pink on the inside.

Within the seals, there's a diversity of seals that you can ferment:

- the hooded seal

- the bearded seal

- the harp seal

- the barbed seal

- the bladdernose seal

The walrus is also still part of the Inuit fermented foods repertoire today.

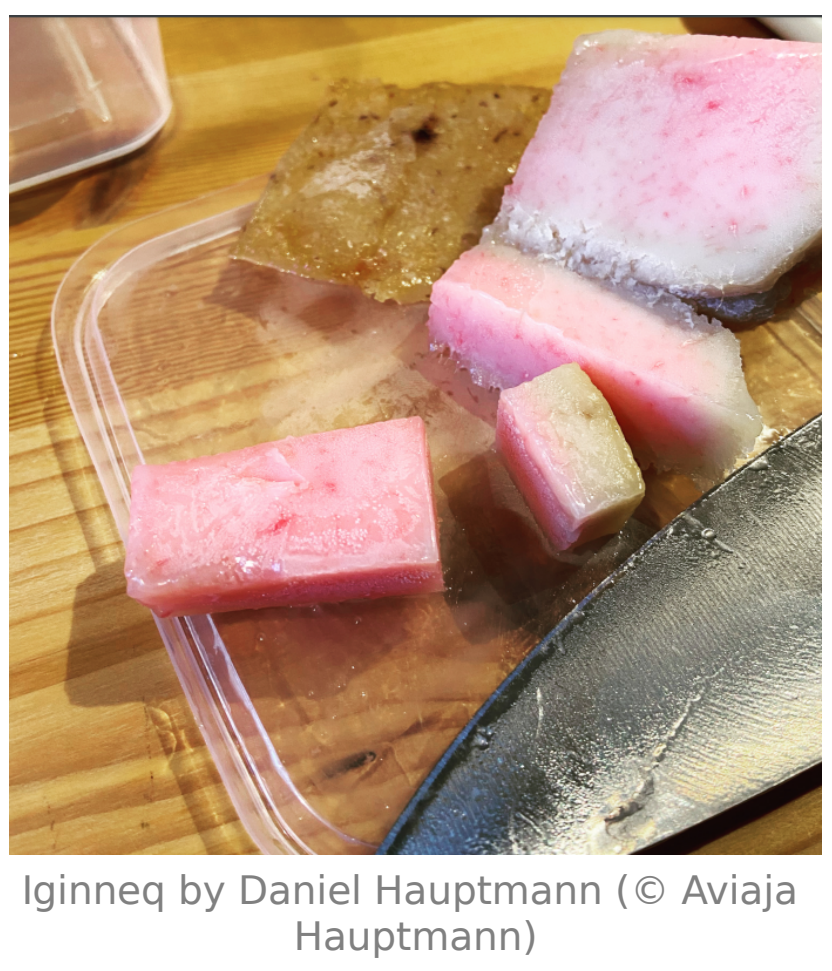


This is an example from Siorapaluk, which is the northernmost permanently populated place on Earth in Greenland.

\section{Visit the web version of this article to view interactive content.}

When you catch a walrus, you add to that batch of fermenting walrus on the inside.

There is a narwhal that you can also ferment (the intestines in particular).

Erik Holtved in Meddelelser om Grønland from 1962 described the use of seal in Greenland as: "to the Greenlanders, seal meat is a nourishing food." He goes on to describe the fermented versions:

'Fermented' is what I call the meat which the Greenlanders store away until it is half putrified; indeed, sometimes it is almost rotten and stinking, for it is rarely so bad that they have to throw it away completely. In order to bring it into this condition they put the meat into blubber pits in summer and cover it with a little blubber; or they leave the blubber on the meat, whereby it quickly becomes tender. In winter, however, the process is not so simple, for then the meat will usually freeze and thus be prevented from putrefying; so they have deep storage pits in the ground, to the deep parts of which the frost cannot get so readily... A whole seal prepared in this fashion is to them the finest dish they can serve to outside visitors.[2]

The quote also tells us that while the European or American explorers that came to the Arctic definitely preferred fresh meat or frozen meat, the Inuit would prefer the fermented variant over the fresh or the frozen. There could be a lot of different reasons, one of which is that it tastes better, but also its nutritional value could be another.

\section{Land Mammals}

Land mammals are also part of the fermentation practice. Not so much the animals themselves, but their intestinal content. An example of a fish that is still made today is a snow fermented cod. 


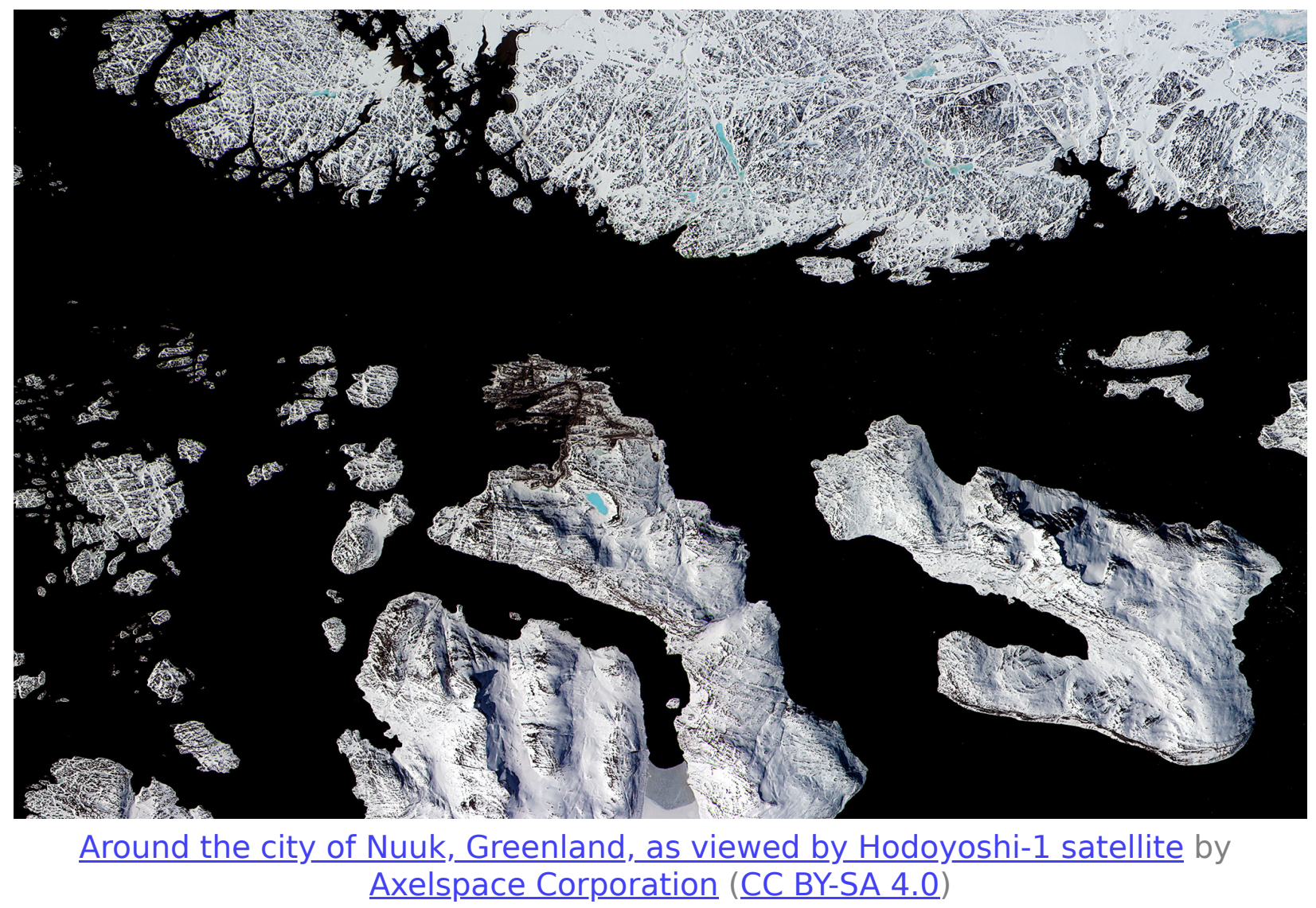

Around January in the capital area of Nuuk, you can put layers of cod and then layers of snow, layers of cod, layers of snow. And then you make your snow fermented cod. And you can do that for about three or four months until it gets too hot. There are also a variety of birds that are a part of the practice. In some cases it's the intestinal content that's eaten in a fermented state or in some versions it's the whole bird, like the little auk, which is made into what is called the kiviaq. And I will be showing how a kiviaq is made in this talk. And then there are also some birds of which the eggs are fermented. 


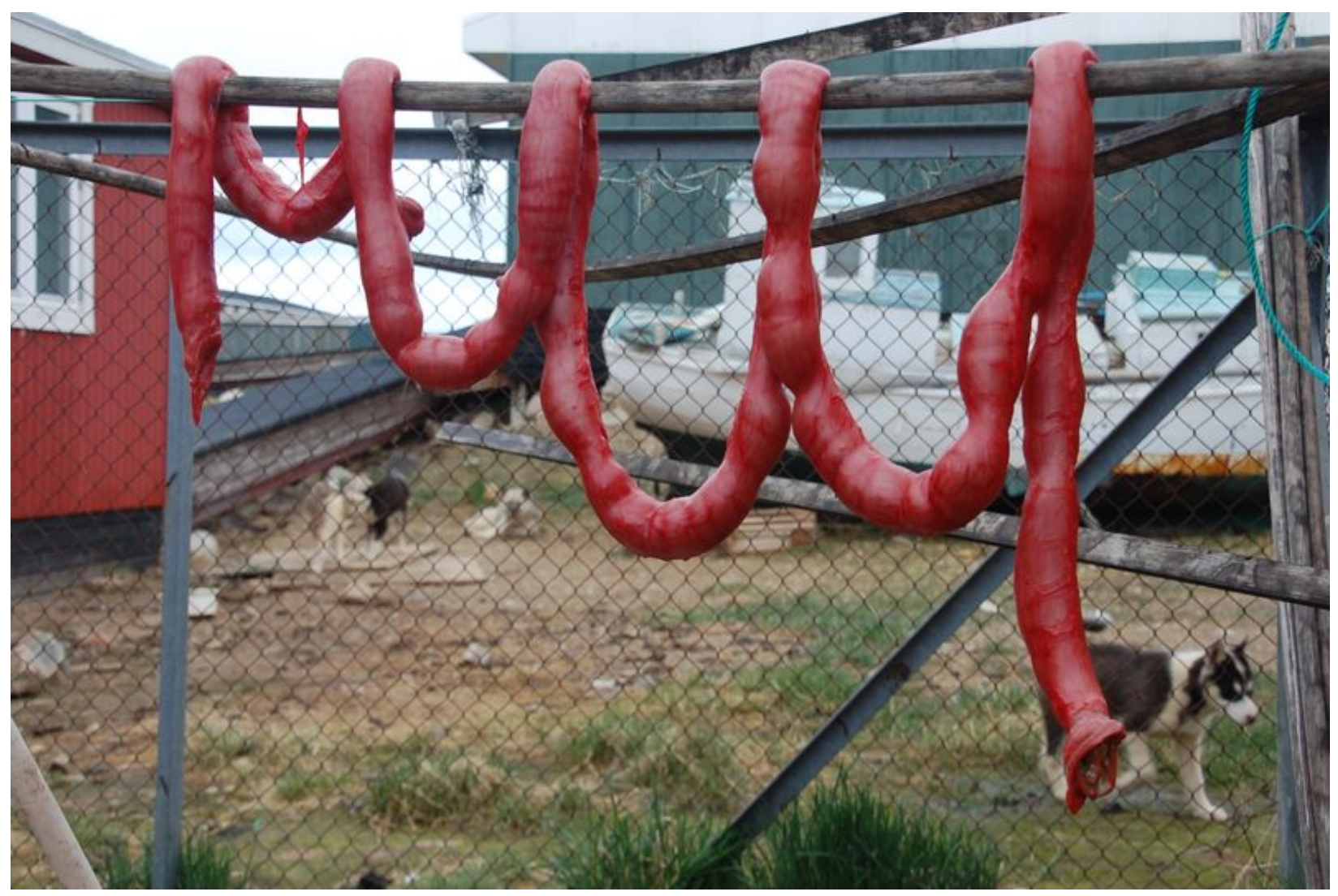

Narwhal intestine drying by Daniel Hauptmann ( (c) Aviaja Hauptmann)

One type of ferment from Greenland that I want to go through is gastrophagy: the eating of intestinal content and intestines.

The above picture shows a drying narwhal intestine. While this isn't considered strictly a fermented food, if you look at the bottom of the narwhal intestine, you can see something sort of oozing out. When you eat this, you have no doubt that there is some fermentation going on. It's rinsed with seawater and freshwater and then it's left to dry. Once it's dry, it gets extremely chewy. It's very difficult to bite through. When you cut it open, the inside is very sticky and caramel-y. I always like to say that while it looks like caramel, it does not taste like caramel at all. It has an incredibly strong flavor like iron, like a lot of sea mammals do. While it's a dried food, it also has some fermentation going on. 

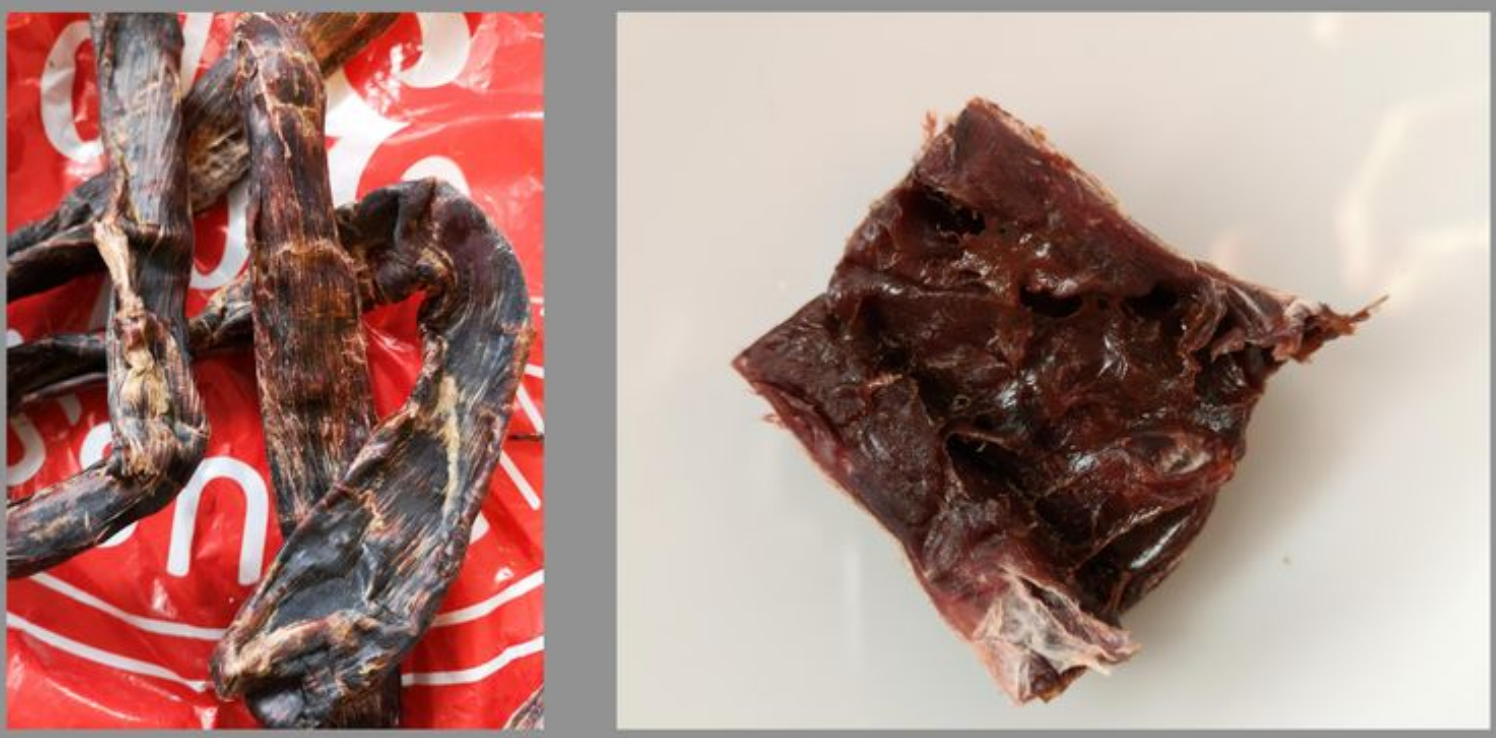

Dried narwhal intestine by Daniel Hauptmann ( ( ) Aviaja Hauptmann)

This is an example where it's not the narwhal intestine but a seal's intestine that's being dried. This is usually used for soups, for instance, where it doesn't get chewy but more like a rubbery texture.

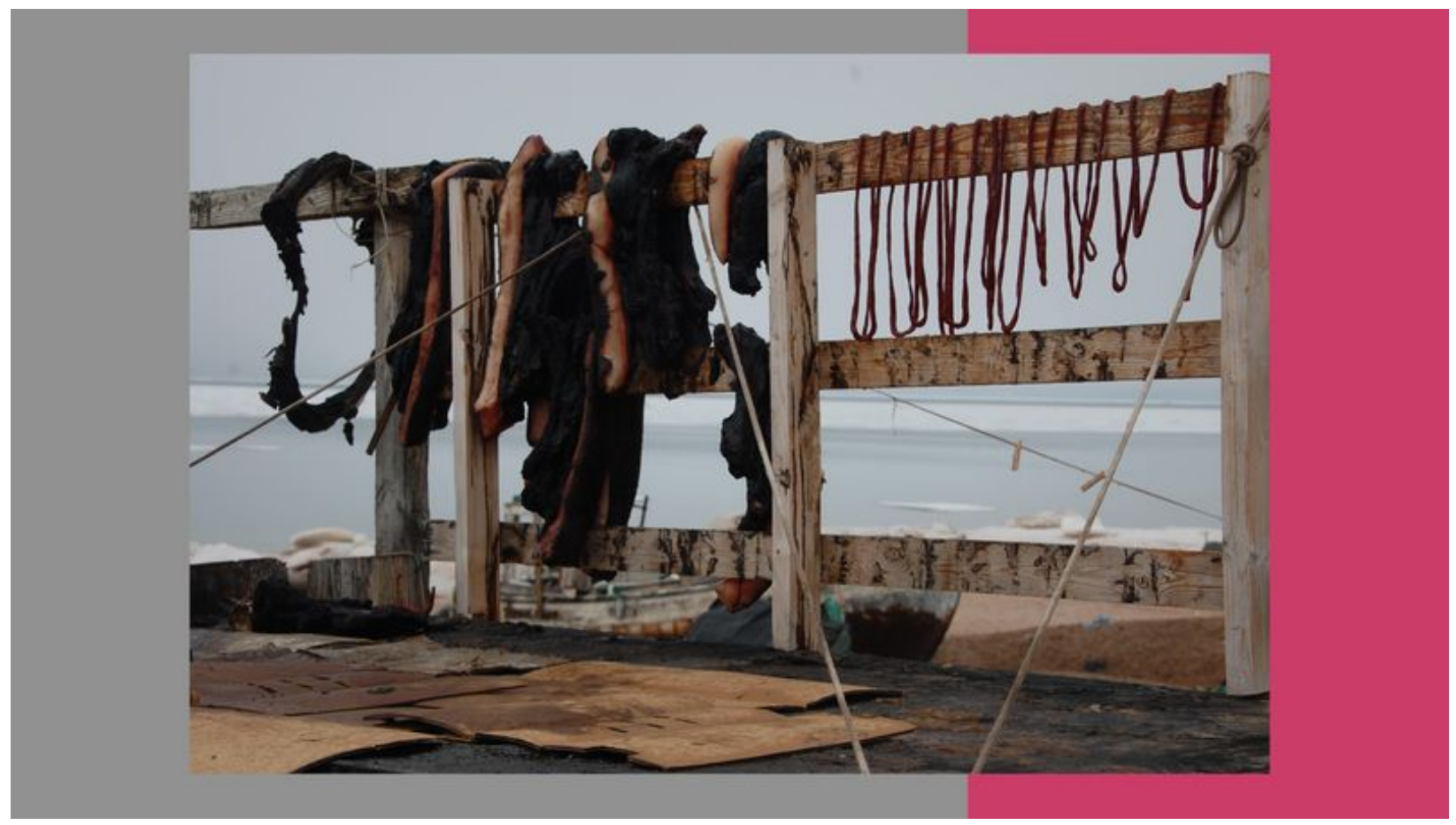

Seal intestine drying by Daniel Hauptmann ( (c) Aviaja Hauptmann) 
There is also the stomach content of a caribou. Maybe 10 years ago, you would be able to go down to the hunter's market and buy bags of this green stuff from the caribou stomach. It's not very common today to eat it, but it used to be considered a delicacy. Kaj_Birket-Smith, an ethnographer in Greenland, described this as "one of the most treasured 'vegetables' are acquired from the animal kingdom so to say, that is the fermented and slightly acidic content of the caribou gut" (1971).[]]

\section{Microbiota}

And to share a little bit of the microbial results that we've made:

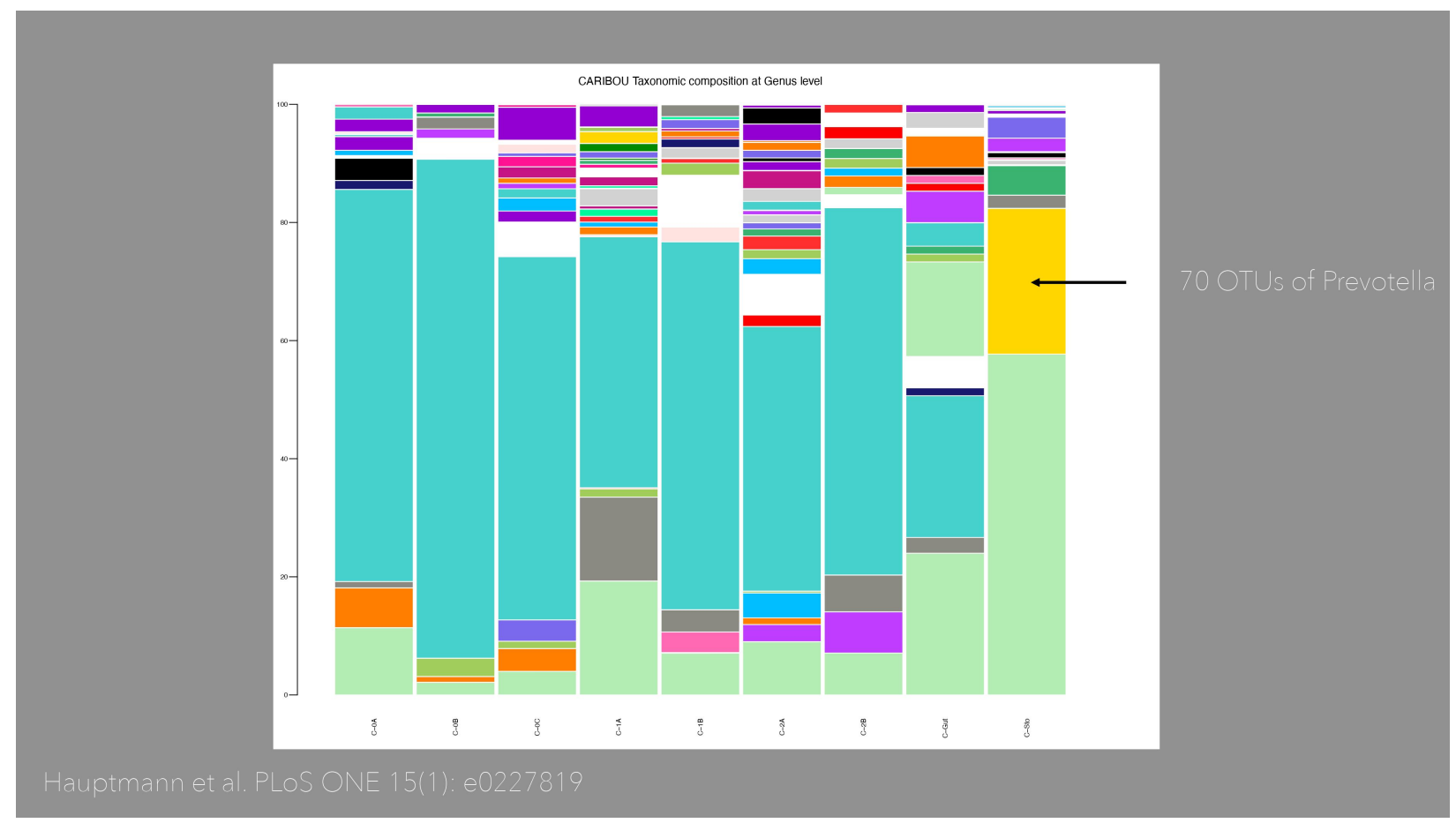

Caribou taxonomic composition at Genus level from Hauptmann AL, Paulová P,_ Hansen LH, Sicheritz-Pontén T, Mulvad G, Nielsen DS (2020) Microbiota in foods from Inuit traditional hunting. PLoS ONE 15(1)_(CC BY 4.0)

What you're seeing is the microbiota, the microbial composition on different pieces of dried caribou meat, because I was following the microbial composition through the drying process. We also included the stomach content, because this is also a food and we wanted to look into the microbiota on the stomach as a food. What was interesting about the microbial content of the stomach is the yellow, because it's not present in any of the other samples. What this large fraction of yellow microbes are is Prevotella and 70 different OTUs of Prevotella. 
This was an interesting finding, because one thing that I realized when looking at this result is that if I had traveled back in time and gone to Greenland 300 years ago and met an original Inuit population in Greenland and I had brought with me the modern diet pyramid and I would have seen these people eat a lot of meat and I would say, you probably need some whole grain to have a healthy gut microbiota. And I would have shared whole grain foods to them. I believe that we wouldn't have gotten the health benefit from those whole grains back then, because as we know, our gut microbiota adapts to the foods that we eat. And if you have a diet as I showed in the beginning with $0 \%$ carbohydrate energy, you would not have had Prevotella in your stomach probably, because you would not have been feeding those microbes that could live off the plant fiber.

When Inuit were eating plants, it would make a lot of sense to eat those high fiber plants in connection to microbes or together with microbes that can degrade these plants. And a fantastic way of doing that is to eat the stomach content of herbivores and even coprophagia, eating the fecal matter of plant eating animals, which also has been part of the diet. So this would be a nice way to prepare for a summer where there might have been a little bit more plant material in the diet. Otherwise you wouldn't have got a lot of energy from that plant material.

\section{Kiviaq fermentation}

And then I want to show how to make the kiviaq. The kiviaq has become quite famous or maybe infamous in fermentation circles. The kiviaq are fermented seabirds. $\underline{1}$

Above we have a very lovely art piece here by my friend Ida showing a kiviaq that we had the fortune to be able to

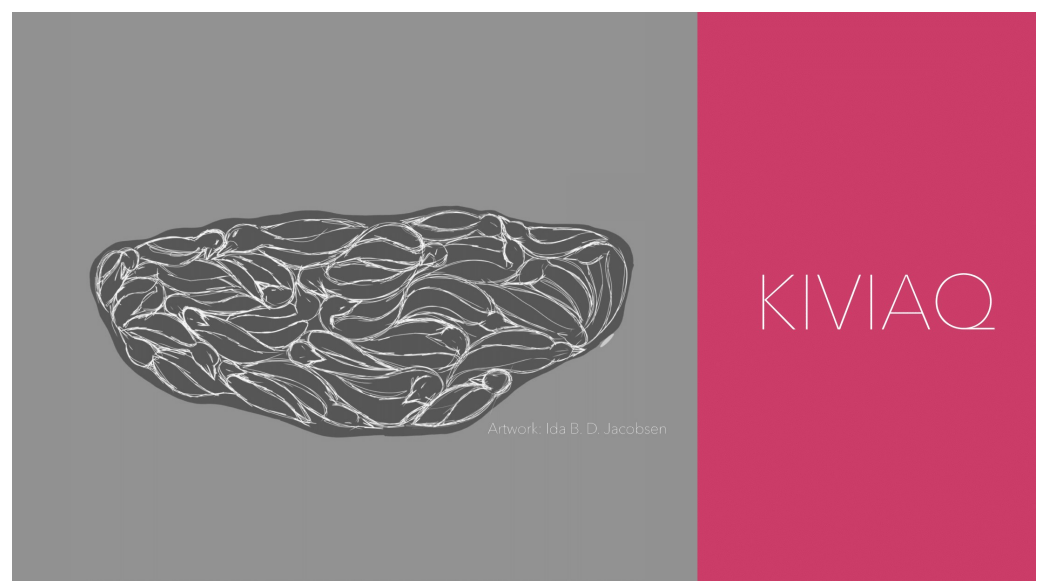

Illustration of kiviaq contents by Ida B. D. Jacobsen experience being made in the very northern part of Greenland in Siorapaluk. 


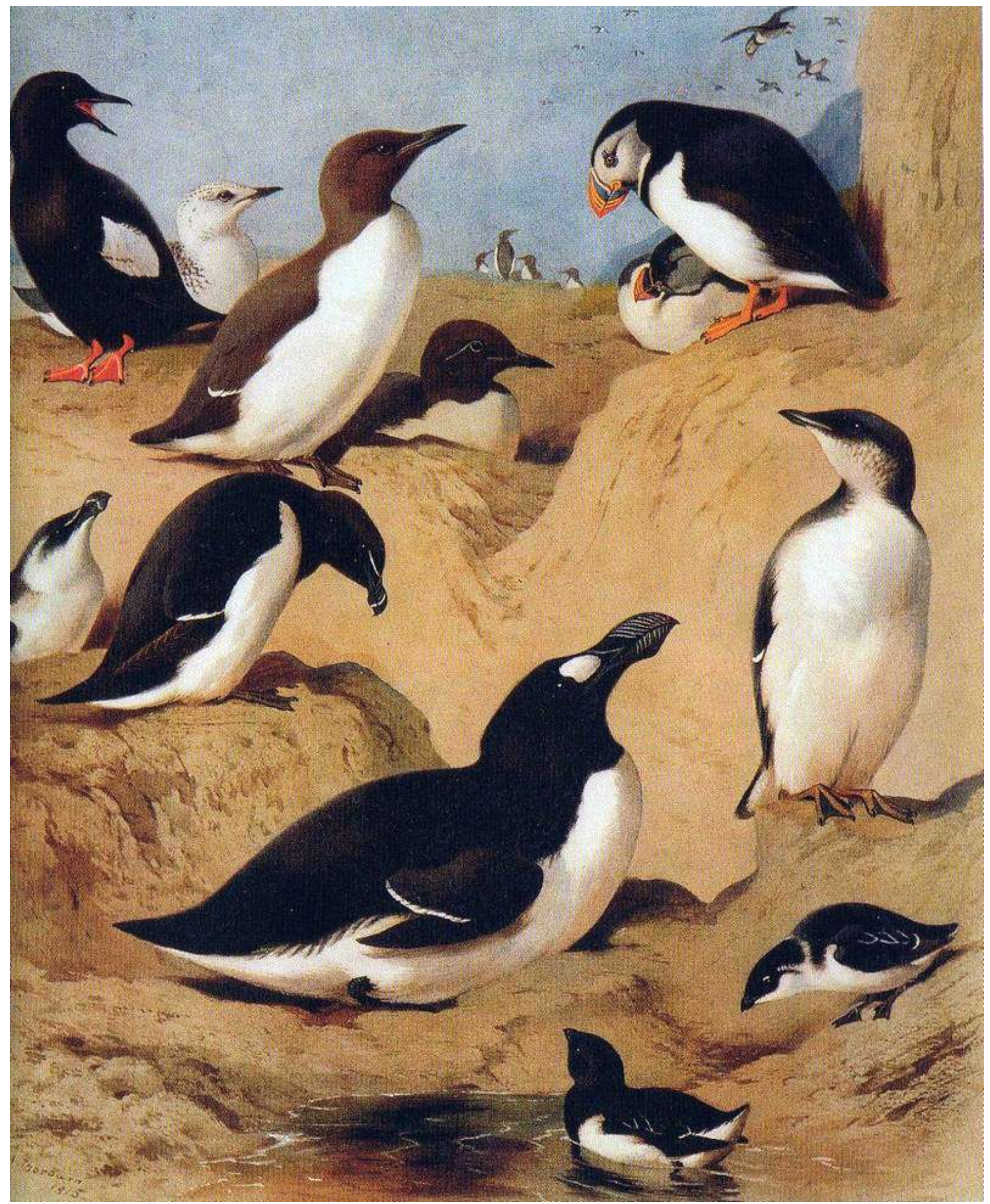

The Great Auk Pinguinus impennis surrounded by its true relatives by Archibald Thorburn (public domain)

Kiviaq are fermented seabirds, but different kinds of seabirds can be fermented. Most often it's the little auk. And the little auk is a tiny bird, about the size of my hand. They 
arrive in northern Greenland in May, and then they stick around for about three months, when they breed. And that's why it also makes a lot of sense to preserve them for use later in the year, because they're there in a such short amount of time.

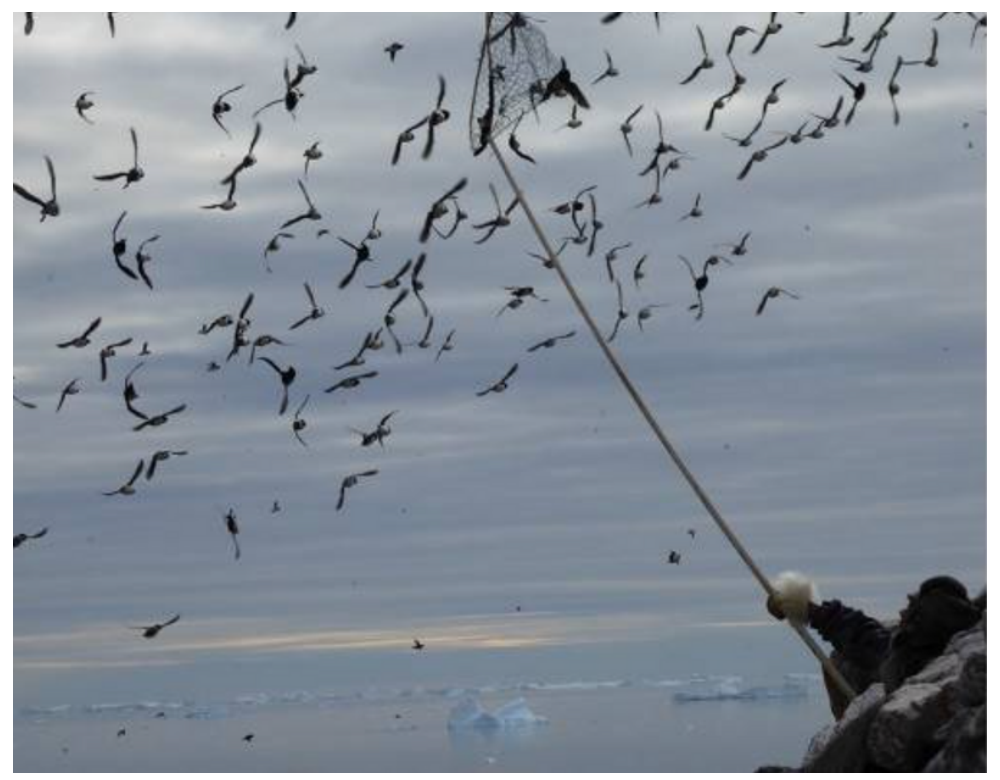

To catch your kiviaq, you use this particular net called kallut. A kallut is around three meters long and very bendy in its handle. And then you crawl up on the cliff side, high up on the cliff side where the birds fly in and out of their nests. Then you catch between 3 and 600 of these birds, depending on the size of the seal skin that you want to stuff the birds into.

Inughuit hunting technique for harvesting little auks. A hunter catching little auks with ipoq from

Once you've caught the birds

a hide in a little auk colony at Qeqertaq (Salve

$\varnothing)$ in the summer of 2014. Photo (c) Anders

Mosbech. Published in Mosbech A, Johansen KL, Davidson TA, et al. On the crucial importance of a small bird: The ecosystem services of the little auk (Alle alle)_population in Northwest Greenland in a long-term perspective. Ambio. 2018;47(Suppl 2):226-243. doi:10.1007/s13280018-1035-x that you need, you need to put them in the shade.

\section{There's a very important primary rule in Inuit fermentation practice, and that is that the sun cannot see the food.}

You have to leave the birds to cool down. They cannot be warm. They have to be the same temperature as the surroundings, which in Siorapaluk in the summertime is probably 0 to 5 degrees Celsius, and make sure that the sun does not see the food.

Once they've cooled down, you can stuff them into that seal skin from which you've taken the seal itself out, leaving just holes at the end. And then you start stuffing in those birds and you squeeze out the air as much as you can. In the end, you stand on top of the kiviaq to make sure that all the air is pressed out. And then once you've stuffed it up, you sew it really nicely like this: 


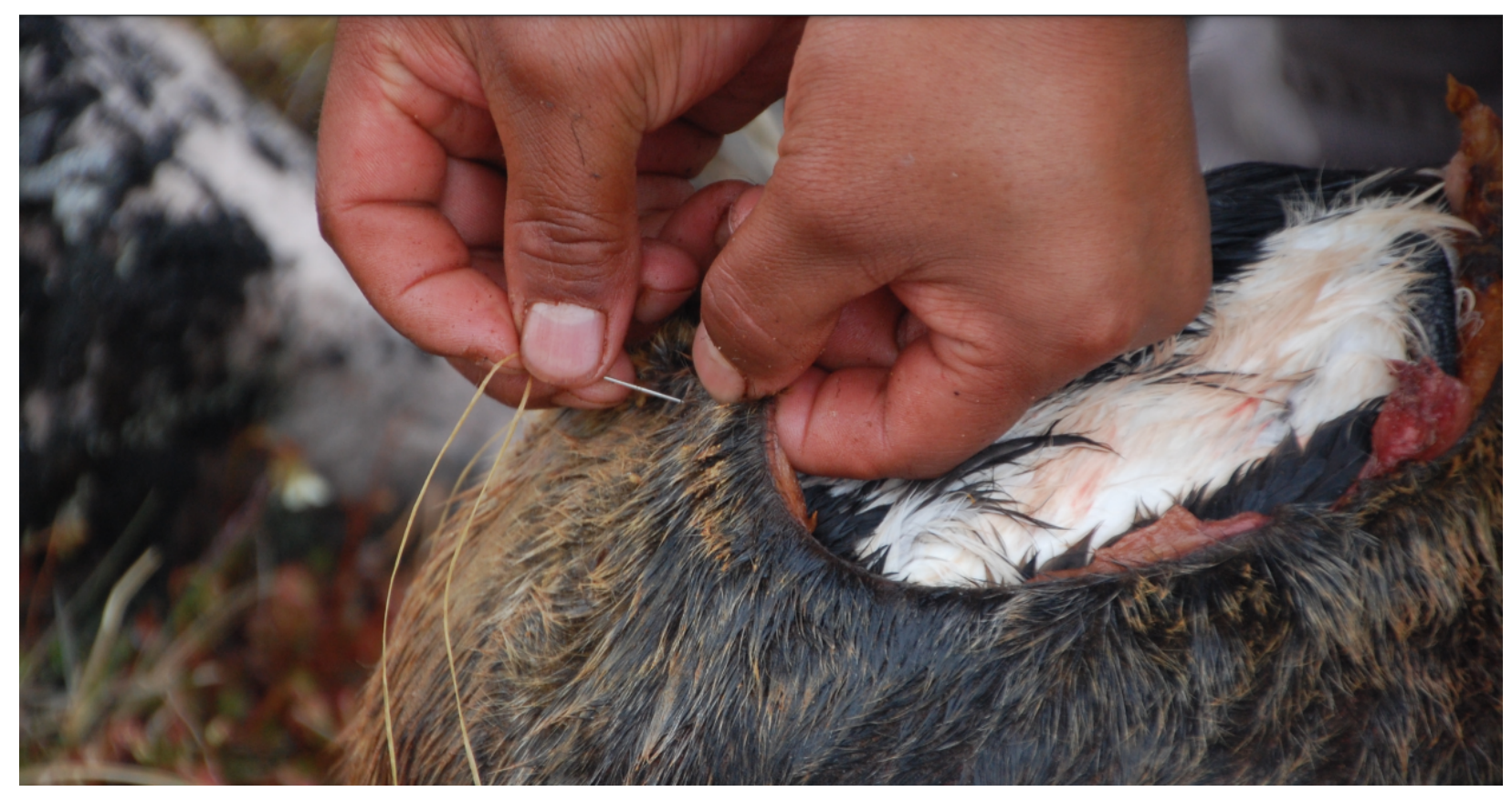

Sewing the kiviaq closed by Daniel Hauptmann ( Aviaja Hauptmann)

And then you stuff any other holes there might be in the seal skin you stuff with birds. And the bird here is not a little auk, because this is quite a big bird as, you can see. This is the guillemot.

In Greenland we call it appa. You can make appa kiviaq or you can make them with the little auk appaliearsuk kiviaq depending on what birds you have in hand or what you want. So the kiviaq that we follow was made from the bigger bird, the appa.

In the end, you have the kiviaq, the seal skin full of seabirds. And this is where this piece of artwork comes in showing how the birds are lying in there all pressed together. 


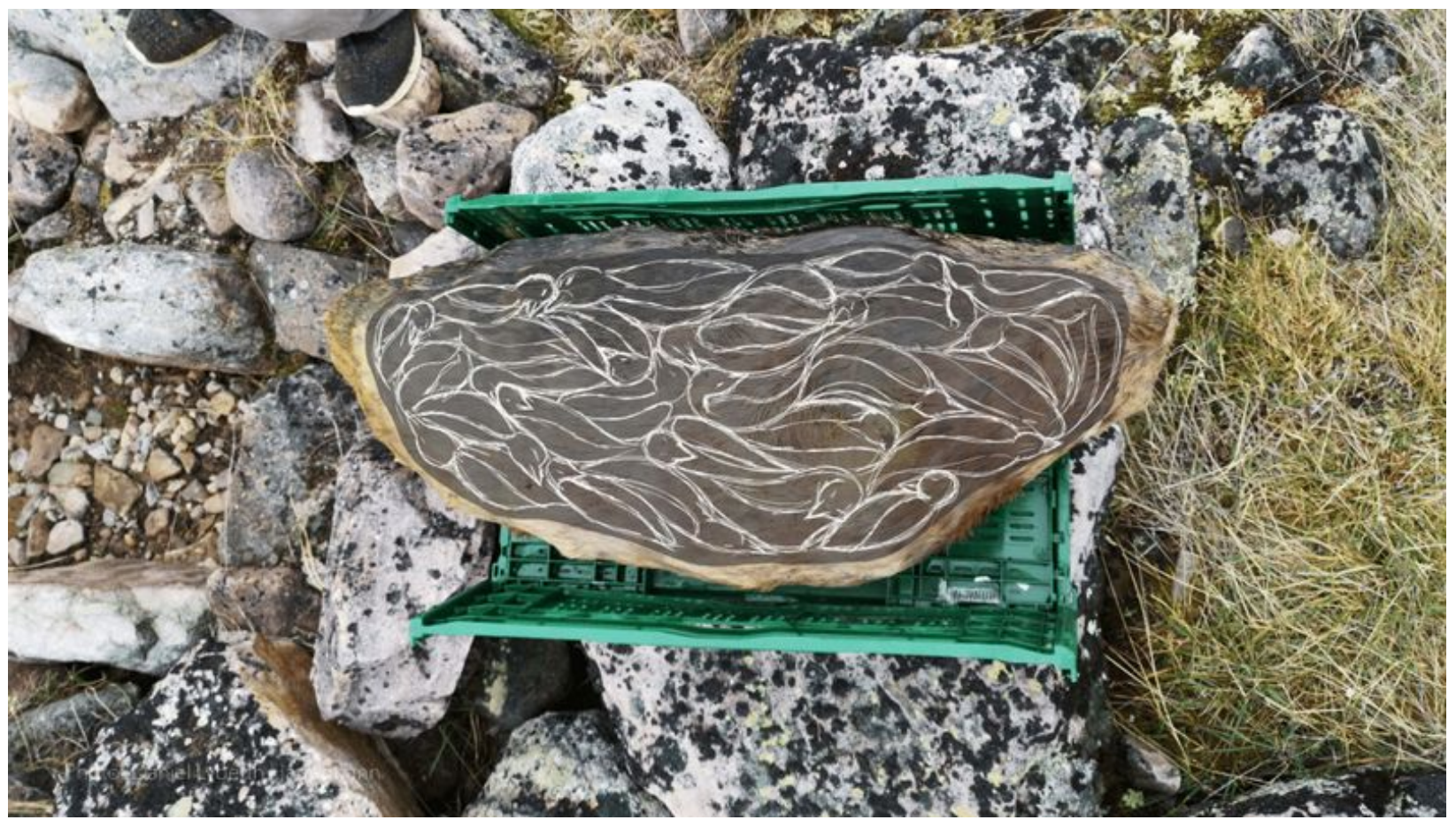

Kiviaq with illustration of contents by Daniel Hauptmann ( (c) Aviaja Hauptmann)

The following process with the kiviaq:

1. After the seal skin is full of seabirds, it is buried in a very shallow pit in the ground.

2. You then cover all the sewed parts with seal blubber to prevent flies from laying eggs there. If they do lay eggs, it's OK. You can still eat the kiviaq. You just brush off the eggs or the mites, but you prefer not to have them.

3. Then you cover with rocks.

4. When it's done depends on the climate, depends on how much sun there was for that year. You have to go and you have to smell and use the aroma to determine whether or not the kiviaq is done.

Visit the web version of this article to view interactive content.

Photos by Daniel Hauptmann ( ( ) Aviaja Hauptmann)

I really think that this is an incredibly beautiful food, although it's become quite infamous.

If you go to YouTube you can find this South Korean documentary about the kiviaq, which is quite interesting. But they use the words "grotesque" and "disgusting," and then there is an article which is a Danish celebrity chef describing how sick he got from eating kiviaq. It's viewed as an extreme type of food, but this doesn't really tell us 
why people make this food and why it's important, which is a new narrative that I would like to promote around our fermented foods.

\section{Eider Egg Fermentation}

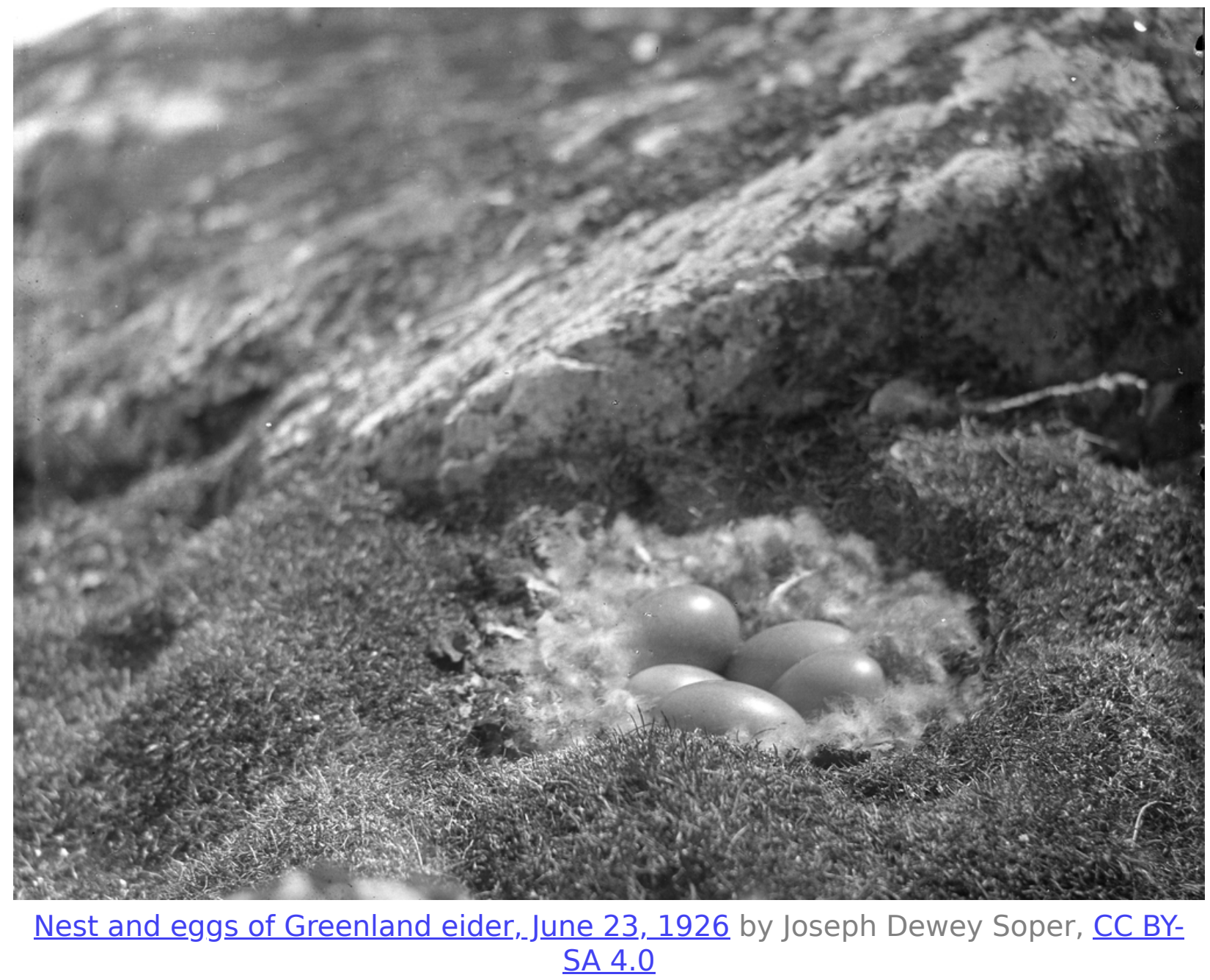

This brings me to the final fermented food that I want to show, the eider egg. So this is the fermented eider egg. The eider is a duck-sized seabird and the eider eggs are also fermented in northern Greenland similarly to the kiviaq, laid in pits with rocks on top of them, but not in the seal skin. And of course, you have to be very careful when you put the rocks on so that the eggs don't break.

After having experienced this food I realized that it's actually illegal in Greenland to collect the eider eggs and it has been for a lot of years. So this food was a really interesting and rare encounter, and it has a really incredible flavor- like cheese. I was fascinated with the fact that these were illegal. 


\section{Food Sovereignty}

When I was there in northern Greenland which, as I mentioned, is the northernmost permanently populated place on Earth, we went to the grocery store. There's one store in town. The town has about less than sixty inhabitants, sixty persons live there. We could buy grapes from Mexico and we could buy kiwi from Chile. So these foods have traveled literally across the planet to come to Siorapaluk, and so to me it is very important that in we in Greenland discuss what kind of food system we promote, why we prefer having foods that have been imported across the planet and then illegalized some of our local foods.

It's a discussion that we need to be having in Greenland. Because what happens when we illegalize, for instance, fermented foods is that our youth are not taught the preparation techniques. We have knowledge disappearing. And when that happens, we know that there's an increased food safety risk from these foods because the knowledge on how to prepare them traditionally is really what prevents food safety risks. And that makes people worry about these foods.

There is a negative feedback loop where the youth have become alienated from our fermented foods in Greenland and across Inuit lands, and then the knowledge disappears even faster. That negative feedback loop is what we risk when we illegalize some of these foods and we promote imported foods instead.

Visit the web version of this article to view interactive content.

Drag the slider to see the differences between a negative and positive feedback loop. Photos by Daniel Hauptmann ( (c) Aviaja Hauptmann)

The inspiration for realizing all of these things come from ICC, the Inuit Circumpolar Council, who have done incredible work on food security and food sovereignty. Their report explores how increasing air temperatures are making it difficult to dry fish.

"Sometimes the fish cooks before it can dry. With rising temperatures, loss of ice cellars and permafrost, new ways of storing food have continued to be explored, such as drying fish within homes.

However, the knowledge of some alternative practices is not being relied upon as heavily. For example, fermenting meat and fish is a good way to store food. It is also highly nutritious. This example demonstrates the importance of documenting 
our practices and continuing to teach our youth through doing so that they will also be able to explore new ways of storing food in the future." [4]

So fermented foods definitely are viewed upon as something that could have a role in the future, but we really need to have a lot of knowledge to be able to do that safely and for that to be promoting of food security.

\section{Visit the web version of this article to view interactive content.}

\section{Indigenous Peoples + Food Sovereignty}

Food security and food sovereignty are very tightly connected to Indigenous peoples and people in general, of course. $\underline{2}$ For Indigenous peoples and for Inuit as well, food sovereignty and food security are very tightly connected. And once we realize that, I think, our fermented foods can go into sort of a positive feedback loop instead.

If we promote our own food sovereignty or food self-determination and we are able to have a resurgence of our fermented foods, we can increase the knowledge and understanding of these foods, which will promote food safety and that will enable us to allow these very nutritious and locally available foods that connect us to land and to culture and to allow them to be part of our food security.

\section{Footnotes}

1. To learn more about this cultural practice, read: Seabird Harvest in the North $\underline{\text { Atlantic, }}$ Catching Birds in the High Arctic, and An Oasis of Open Water from Hakai Magazine. $\uplus$

2. To learn more, please read "Greenlandic researcher explores the power of Inuit food" by Jane George from the Nunatsiaq News (2018). $\subseteq$

\section{Citations}

1. Peder Helms, Ernæringsforskningen i Grønland, Tidsskriftet Grønland 5 (1986)

2. Erik Holtved, ed. Otto Fabricius' Ethnographical Works. Meddelelser om Grønland 140(2), 1962.

3. Kaj Birket-Smith, Eskimos, New York: Crown Publishing (1971). 
4. Inuit Circumpolar Council-Alaska. 2015. Alaskan Inuit Food Security Conceptual Framework: How to Assess the Arctic From an Inuit Perspective. Technical Report. Anchorage, $\mathrm{AK} \subseteq$ 